\title{
Characterization of Chicken By-products by Mean of Proximate and Nutritional Compositions
}

\author{
Pil Nam Seong ${ }^{1}$, Soo Hyun Cho ${ }^{1}$, Kuyng Mi Park', Geun Ho Kang ${ }^{1}$, Beom Young Park ${ }^{1}$, \\ Sung Sil Moon ${ }^{2}$, and Hoa Van $\mathrm{Ba}^{1, *}$ \\ ${ }^{1}$ Animal Products and Processing Division, National Institute of Animal Science, Wanju 565-851, Korea \\ ${ }^{2}$ Sunjin Meat Research Center, Seoul 134-822, Korea
}

\begin{abstract}
Though a great amount of chicken by-products are consumed everyday in many countries worldwide, however, no attention has been paid to the investigation of nutritional composition of these by-products. In the present work, the basic information regarding the aspects of nutritional composition of chicken by-products such as; liver, gizzard, heart, lung, crop, small intestines, cecum and duodenum was studied. Our results revealed that the approximate composition range (minimum to maximum) of these by-products was found as such: moisture 76.68-83.23\%; fat 0.81-4.53\%, protein 10.96-17.70\% and calories $983.20-1,426.0 \mathrm{cal} / \mathrm{g}$ tissue, in which liver and gizzard had the highest protein content. Liver had higher $(p<0.05)$ vitamin A, B1, B2, B3, B5 and B6 contents in comparison to other remaining byproducts. Total saturated fatty acids (SFA), unsaturated fatty acids (UFA), polyunsaturated fatty acids (PUFA) levels ranged between the by-products from $31.82 \%$ to $43.96 \%, 56.04 \%$ to $68.19 \%$, and $18.27 \%$ to $32.05 \%$, respectively. Remarkably, all of by-products showed desirable PUFA/SFA ratios. Furthermore, all of chicken by-products, especially liver, contained higher levels of trace elements (e.g., Fe, $\mathrm{Mn}$ and $\mathrm{Zn}$ ) in comparison with those from muscle tissues published in literature. Overall, the study indicated that most of chicken byproducts examined are good sources of essential nutrients and these obtained results will be the useful information to consumers and meat processors.
\end{abstract}

Key words: chicken by-products, vitamin, mineral, amino acid, fatty acid contents

Received October 13, 2014 / Revised January 7, 2015 / Accepted January 14, 2015

\section{Introduction}

As we known, the world meat consumption has greatly increased in recent times compared to that before the 1989 s as a result of the income and population growths. The growing demand for meat involves a wide variety of meat types from different animal species for instance; beef, pig, horse and chicken etc. Of which, chicken apparently is one of the most commonly consumed meat types in most of religions and cultures in the world. According to the data reported by the Poultry Site (2013), the World's chicken meat consumption expanded from 66.4 million tons back in 2000 to 91 million tons in 2009 and reached almost 94 million tons in 2013, in which the consumption of Asia accounted for $40 \%$ of the world total. This implies that a considerable amount of the chicken by-prod-

\footnotetext{
*Corresponding author: Hoa Van Ba, Animal Products and Processing Division, National Institute of Animal Science, Wanju 565-851, Korea. Tel: +82-63-238-7352, Fax: +82-63-238-7397, E-mail: hoavanba@jbnu.ac.kr
}

ucts is produced every day from slaughterhouses. The edible chicken by-products generally comprise some products such as; internal organs such as; heart, liver, spleen and kidney, which constitute a significant ratio of live weight of a chicken, with their yields range from 5-6\% depending upon animal age (Ockerman and Basu, 2004).

However, the consideration and utilization of the meat by-products basically depends upon a number of factors such as culture, religion and preference etc. Hence, some by-products those are considered inedible in a country but can be considered as precious products in other countries (Toldra et al., 2012). In general, however, the edible chicken by-products are widely used in most of countries worldwide in different traditional dishes for instance; in United States, the giblets of chicken are commonly consumed, while all of edible parts of chicken offal are often used for making Japanese traditional dishes. Similarly, the edible chicken by-products are salvaged and used for human consumption in most of Asian countries including Korea (Nollet and Toldrá, 2011).

For the past decades, most of studies have only focused 
on chicken muscle tissue in terms of meat quality measurement (Jeon et al., 2010; Kim et al., 2009) and processing methods (Bonoli et al., 2007; Choi et al., 2010), with a great amount of scientific information regarding its quality and utilization is available and can review elsewhere as mentioned above. So far, there have been some studies which investigated the nutritional values of edible meat by-products, but all of these studies only focused on meat by-products from species such as pig (Seong et al., 2014a), bovine (Seong et al., 2014b), sheep (Hoffman et al., 2013) and buffalo (Devatkal et al., 2004). Whereas, the edible meat by-products from chicken are also widely used as human foods in most countries, however, very few reports have published on the nutritional quality of these meat by-products. While the edible meat by-products from chicken origin account for a significant ratio of live weight and are the important ingredients in human dishes, simultaneously, such abundant available source probably produces good opportunities for the meat processors in utilization of them to increase economic profitability as well as reduce the loss of this valuable source of revenue. Thus, the main objective of the present study was to investigate the proximate and nutritional compositions of majority of chicken by-products.

\section{Materials and Methods}

\section{Sample preparation}

Ross breed chickens $(n=50)$ at approximately 4 mon of age with their live weights of 2.0-3.0 kg randomly selected from the commercial chicken breeds at a local farm (Korea) were used in the present research. The animals were transported to an abattoir of the National Institute of Animal Science, Suwon, Korea, where the animals were slaughtered. After slaughter, whole internal organs of each chicken were collected and then carefully separated into individual parts such as; heart, lung, liver, gizzard, cecum, crop, small intestine and duodenum. For the parts of digestive tract, which were split before washing, thereafter the selected offal samples were washed under running tap water to remove adhering blood, food remnants and feces, and were then trimmed off of visible fats and connective tissues. After draining the water, each offal type was placed in individual plastic bag and vacuum-packaged. Thereafter, the offal samples from each 10 animals were randomly taken and used for each type of analysis either proximate composition or vitamin, mineral, amino acid and fatty acid contents. The samples used for proximate composition were stored at $2^{\circ} \mathrm{C}$ in a chilling room while those used for the nutritional composition analysis were stored at $-20^{\circ} \mathrm{C}$ until use.

\section{Proximate composition and calorie}

Moisture, fat and protein contents were analyzed using the method of the Association of Official Analytical Chemists (AOAC, 2000). Particularly, the moisture and fat contents were determined by using a moisture $\&$ fat analyzer (SMART Trac, CEM Corp, USA); while, the nitrogen content was determined by using a nitrogen analyzer (Rapid N cube, Elementar, Germany) and then converted into protein content using the $\mathrm{N} \times 6.25$ equation $(\mathrm{N}=$ nitrogen content obtained from the samples, and $6.25=$ conversion factor). To determine calorie, the offal sample was homogenized in a blender (HMF 3160S, Hanil Co., Korea), then the homogenate was used for measurement of calorie content by using a calorimeter (model 6400, Parr instrument, USA). Calories were expressed as cal $/ \mathrm{g}$ of the sample.

\section{Vitamin content}

Vitamins (vitamin A, B1, B2, B3, B5 and B6) in the by-products were determined by following the procedures of AOAC (2000) using a reversed-phase high performance liquid chromatography (RP-HPLC) (Aglient 1200 series, Aglient, USA).

\section{Fatty acid composition}

Total lipid was extracted according to the methods of Folch et al. (1957) and Morrison and Smith (1964). Subsequently, the fatty acids were analyzed using a gas chromatograph system (Varian star 3600, Varian, Inc., CA) equipped with flame ionization detector and Omegawax 205 fused-silica bond capillary column $(30 \mathrm{~m} \times 0.32 \mathrm{~mm}$ $\times 0.25 \mu \mathrm{m}$ film thickness). The initial and final temperatures of the oven were $140^{\circ} \mathrm{C}$ and $230^{\circ} \mathrm{C}$, respectively. The injector port and detector temperatures were $250^{\circ} \mathrm{C}$ and $260^{\circ} \mathrm{C}$ respectively. Individual fatty acids were confirmed on the basis of retention time through comparison with a commercially available mixture of fatty acids (PUFA No.2-Animal Source, Supelco, USA). The fatty acid profile was expressed as percentage of individual fatty acids identified.

\section{Amino acid content}

Samples used for amino acid analysis were hydrolyzed with $6 \mathrm{~N} \mathrm{HCl}$ solution for $24 \mathrm{~h}$ at $110^{\circ} \mathrm{C}$. The hydrolyzed samples were concentrated at $50^{\circ} \mathrm{C}$ and then diluted with $50 \mathrm{~mL}$ of $0.2 \mathrm{~N}$ sodium citrate buffer ( $\mathrm{pH} 2.2$ ), and finally 
were filtered through $0.45 \mu \mathrm{m}$ filters (Millipore Corp., Biedford, USA). The amino acids were determined by applying the filtrates (30 $\mu \mathrm{L}$ each) to an amino acid analyzer (model 8900A) equipped with an exchange column $(4.6 \mu 60 \mathrm{~mm})$ (Hitachi, Japan). The separation and detection of amino acids were carried out using the method as described by Spackman et al. (1958).

\section{Mineral content}

Mineral content was determined by following the method of AOAC (2000). Briefly, five grams of each sample was destroyed by dry ashing in a microwave ashing oven (MAS 7000, CEM Corp., USA) for $12 \mathrm{~h}$ with a final temperature of $600^{\circ} \mathrm{C}$. The ash content was dissolved in 10 $\mathrm{mL}$ of $37 \% \mathrm{HCl}$ and distilled water $(1: 1 \mathrm{v} / \mathrm{v})$ solution and was then filtered through Whatman filter paper (No.6) (AEC scientific Co., Korea). Minerals including $\mathrm{Na}$ (selected wavelength $588.9 \mathrm{~nm}), \mathrm{K}(766.5 \mathrm{~nm}), \mathrm{Ca}(422.7 \mathrm{~nm})$, Mg (285 nm), P (470 nm), Fe (248.3 nm), and Zn (213.9 $\mathrm{nm}), \mathrm{Mn}(279.5 \mathrm{~nm}), \mathrm{Cu}(324.7 \mathrm{~nm})$ and $\mathrm{Cr}(357.9 \mathrm{~nm})$ were determined by atomic emission spectrophotometer ICP-OES (Spectro, Boschstr, Germany). A calibration curve was prepared for each element.

\section{Statistical analysis}

The data were collected and then subjected to statistic analysis using the Statistic Analysis System (SAS) package (2007). All data were analyzed by the General Linear Model (GLM) procedure considering the by-product type as the main effect. Means were compared using Duncan's Multiple Range Test, with a significance of $p<0.05$.

\section{Results and Discussion}

\section{Proximate composition of chicken by-products}

The major proximate compositions of chicken by-products were determined and the results are shown in Table 1. The results revealed that the moisture content varied among the by-products, ranging from $76.68 \%$ to $83.23 \%$, with the highest value was found in lung and the lowest value was found in liver. In general, the chicken by-products (e.g., liver and heart) had higher moisture content compared with those in corresponding by-products from pork and beef origins (Seong et al., 2014a, 2014b). The fat content differed significantly $(p<0.05)$ among the byproducts examined; heart had the highest level $(4.53 \%)$, followed by liver $(2.89 \%)$, cecum $(2.55 \%)$, duodenum (2.46\%), lung (1.9\%) and crop (1.81\%), while the gizzard had the lowest level $(0.81 \%)$. The fat contents in by-products in the present study were almost similar to the values reported for by-products of similar species in literature (Honikel, 2011). The chicken liver had slightly lower fat content, and chicken heart had higher fat content compared with those in beef liver and heart (Seong et al., 2014b). Similarly, Seong et al. (2014a) reported similar fat levels in pork heart (4.55\%) and liver (2.94\%), and Hoffman et al. (2013) reported higher fat contents in cooked heart (16.4\%), liver $(9.7 \%)$ and lung $(4.6 \%)$ of sheep. Daily fat intake is important for human health because the fat not only contributes to energy intake but also helps vitamin absorbance, however, a high daily fat intake has been associated with some diseases such as; obesity and cardiovascular disease (Bray et al., 2004). In the present study, it was found that the fat levels of by-products were generally similar and even lower than those of muscle tissues of the same and other animal species.

Protein content widely varied among the by-products; particularly, liver and gizzard had the highest values (17.70\% and $17.26 \%$, respectively), crop had lower value $(15.81 \%)$ and lung had the lowest level (10.96\%) ( $p<$ 0.05 ). The results of the present study were in accordance with those reported for the chicken offal (Honikel, 2011). The differences in protein contents could be attributed due to the differences in the inherent properties, type and quantity of proteins that constitute these by-products. When compared to the protein contents of some of meat

Table 1. Proximate compositions of chicken by-products

\begin{tabular}{ccccc}
\hline \hline Item & Moisture (\%) & Fat (\%) & Protein (\%) & Calorie (cal/g) \\
\hline Liver & $76.68 \pm 0.10^{\mathrm{d}}$ & $2.89 \pm 0.08^{\mathrm{b}}$ & $17.70 \pm 0.06^{\mathrm{a}}$ & $1426.00 \pm 18.02^{\mathrm{a}}$ \\
Gizzard & $79.94 \pm 0.30^{\mathrm{c}}$ & $0.81 \pm 0.09^{\mathrm{e}}$ & $17.26 \pm 0.14^{\mathrm{a}}$ & $1183.00 \pm 16.59^{\mathrm{c}}$ \\
Cecum & $82.21 \pm 0.41^{\mathrm{ab}}$ & $2.55 \pm 0.11^{\mathrm{c}}$ & $11.98 \pm 0.63^{\mathrm{d}}$ & $1022.20 \pm 29.12^{\mathrm{d}}$ \\
Crop & $81.09 \pm 0.08^{\mathrm{bc}}$ & $1.81 \pm 0.07^{\mathrm{d}}$ & $15.81 \pm 0.23^{\mathrm{b}}$ & $1300.80 \pm 15.53^{\mathrm{b}}$ \\
Small intestine & $82.61 \pm 0.90^{\mathrm{a}}$ & $1.82 \pm 0.07^{\mathrm{d}}$ & $11.78 \pm 0.17^{\mathrm{d}}$ & $995.00 \pm 17.89^{\mathrm{d}}$ \\
Heart & $77.36 \pm 0.38^{\mathrm{d}}$ & $4.53 \pm 0.13^{\mathrm{a}}$ & $13.83 \pm 0.12^{\mathrm{c}}$ & $1320.00 \pm 20.11^{\mathrm{b}}$ \\
Duodenum & $82.95 \pm 0.31^{\mathrm{a}}$ & $2.46 \pm 0.10^{\mathrm{c}}$ & $12.18 \pm 0.18^{\mathrm{d}}$ & $1044.40 \pm 19.76^{\mathrm{d}}$ \\
Lung & $83.23 \pm 0.24^{\mathrm{a}}$ & $1.90 \pm 0.13^{\mathrm{d}}$ & $10.96 \pm 0.12^{\mathrm{e}}$ & $983.20 \pm 17.26^{\mathrm{d}}$ \\
\hline
\end{tabular}

Means in the same column with different superscripts (a-d) are significantly different $(p<0.05)$. 
by-products (e.g., heart and liver) from other animal species such as pork (Seong et al., 2014a) and beef (Seong et al., 2014b), the liver and heart from chicken origin had generally lower protein content. Earlier workers (Hoffman et al., 2013) reported similar protein level (13.5\%) for sheep heart. In general, the protein contents in some of chicken by-products were comparable to the level of raw pork chop (17.3\%) and higher than that in duck meat $(12.3 \%)$, however, most of them had lower values compared with those in common muscle tissues such as chicken and beef (Pereira and Vicente, 2013).

For calorie, it was observed that the highest value was found in liver, followed by heart, crop and gizzard, while the lowest were found in lung, small intestine and cecum. The calories of by-products in the present study were almost similar the values reported for the chicken offal in literature (Honikel, 2011) but lower than those reported for the pork offal (Seong et al., 2014a). The recommended daily allowance (RDA) for an adult male is $60 \mathrm{~g}$ protein, $90 \mathrm{~g}$ dietary fat and $2500 \mathrm{kcal}$ (Honikel and Schwagele, 2007), therefore, for example; a consuming $100 \mathrm{~g}$ of chicken liver would supply $29.5 \%$ of protein, $3.2 \%$ fat and $5.7 \%$ total energy.

\section{Vitamin content of chicken by-products}

It has long been recognized that vitamins are essential compounds that maintain the normal function and metabolic reactions in the body because most vitamins cannot be made in body, so they must be supplied from foods. In the present study, the major vitamins in chicken by-products were determined and the results showed that the amounts of vitamins varied considerably among the byproducts examined (Table 2). Regarding the vitamin A, liver had the highest level $(21,676.18 \mu \mathrm{g}$ RE/100g of raw sample). Noticeably, the level of vitamin A in liver was thousands of times greater than those in the other remain- ing by-products. These results were in accordance with those reported for the offal of similar species (Honikel, 2011). Additionally, it was observed that the vitamin A content in chicken liver was similar the value reported for pork liver but higher than the value found in beef liver (Kim, 2011). Whereas, chicken heart contained much higher vitamin A content compared with those of offal from pork, beef and sheep species (Honikel, 2011; Seong et al., 2014a).

Similarly, the vitamin B1 content ranged between the by-products from $0.01 \mathrm{mg} / 100 \mathrm{~g}$ to $0.23 \mathrm{mg} / 100 \mathrm{~g}$ of sample, in which the highest was found in liver and the lowest was found in duodenum samples. The vitamin B1 content in chicken by-products was almost equal to the values reported for the offal from chicken and other species in literature (Kim, 2011; Honikel, 2011). On the other hand, when compared to the vitamin B1 content of chicken breast muscle $(0.06-0.12 \mathrm{mg} / 100 \mathrm{~g})$ and beef muscle $(0.07-0.10$ $\mathrm{mg} / 100 \mathrm{~g}$ sample) (Zotte and Szendro, 2011), most of chicken by-products examined had higher vitamin B1 content.

The vitamin B2, B3, B5 and B6 contents ranged between the by-products examined from $0.1-0.74 \mathrm{mg} / 100 \mathrm{~g}$, $0.33-6.57 \mathrm{mg} / 100 \mathrm{~g}, 0.22-4.16 \mathrm{mg} / 100 \mathrm{~g}$ and $0.001-0.01$ $\mathrm{mg} / 100 \mathrm{~g}$ raw sample, respectively. Amongst, the liver contained the highest levels of these vitamins, followed by heart, and the other remaining by-products had lower levels. This finding agrees well with that of Seong et al. (2004a, 2004b), who found that the levels of all vitamins in liver and heart were generally higher than those in other remaining by-products from pork and beef species. Furthermore, the levels of these vitamins B in most of chicken by-products examined were higher than those in the muscle tissues from chicken beef, rabbit and pork (Zotte and Szendro, 2011). This is in good agreement with the previous observations of Kim (2011) which indicated that internal organs have more vitamin contents than mu-

Table 2. Vitamin content of chicken by-products

\begin{tabular}{ccccccc}
\hline \hline Item & $\begin{array}{c}\text { Vitamin A } \\
(\mu \mathrm{gRE} / 100 \mathrm{~g})\end{array}$ & $\begin{array}{l}\text { Vitamin B1 } \\
(\mathrm{mg} / 100 \mathrm{~g})\end{array}$ & $\begin{array}{l}\text { Vitamin B2 } \\
(\mathrm{mg} / 100 \mathrm{~g})\end{array}$ & $\begin{array}{l}\text { Vitamin B3 } \\
(\mathrm{mg} / 100 \mathrm{~g})\end{array}$ & $\begin{array}{l}\text { Vitamin B5 } \\
(\mathrm{mg} / 100 \mathrm{~g})\end{array}$ & $\begin{array}{c}\text { Vitamin B6 } \\
(\mathrm{mg} / 100 \mathrm{~g})\end{array}$ \\
\hline Liver & $21,676.18 \pm 3,439^{\mathrm{a}}$ & $0.23 \pm 0.02^{\mathrm{a}}$ & $0.74 \pm 0.05^{\mathrm{a}}$ & $6.57 \pm 0.19^{\mathrm{a}}$ & $4.16 \pm 0.15^{\mathrm{a}}$ & $0.01 \pm 0.00^{\mathrm{a}}$ \\
Gizzard & $13.46 \pm 5.30^{\mathrm{b}}$ & $0.04 \pm 0.01^{\mathrm{d}}$ & $0.11 \pm 0.00^{\mathrm{d}}$ & $3.84 \pm 0.15^{\mathrm{c}}$ & $0.81 \pm 0.03^{\mathrm{d}}$ & $0.001 \pm 0.00^{\mathrm{b}}$ \\
Cecum & $7.28 \pm 2.35^{\mathrm{b}}$ & $0.01 \pm 0.00^{\mathrm{f}}$ & $0.11 \pm 0.02^{\mathrm{d}}$ & $0.33 \pm 0.08^{\mathrm{g}}$ & $0.22 \pm 0.05^{\mathrm{g}}$ & $0.001 \pm 0.00^{\mathrm{b}}$ \\
Crop & $10.68 \pm 1.58^{\mathrm{b}}$ & $0.15 \pm 0.01^{\mathrm{b}}$ & $0.51 \pm 0.01^{\mathrm{c}}$ & $3.04 \pm 0.06^{\mathrm{d}}$ & $1.44 \pm 0.03^{\mathrm{c}}$ & $0.001 \pm 0.00^{\mathrm{b}}$ \\
Small intestine & $13.24 \pm 7.35^{\mathrm{b}}$ & $0.02 \pm 0.00^{\text {ef }}$ & $0.13 \pm 0.01^{\mathrm{d}}$ & $0.86 \pm 0.08^{\mathrm{f}}$ & $0.32 \pm 0.03^{\mathrm{f}}$ & $0.001 \pm 0.00^{\mathrm{b}}$ \\
Heart & $31.90 \pm 6.96^{\mathrm{b}}$ & $0.13 \pm 0.02^{\mathrm{c}}$ & $0.66 \pm 0.04^{\mathrm{b}}$ & $4.29 \pm 0.10^{\mathrm{b}}$ & $3.84 \pm 0.09^{\mathrm{b}}$ & $0.001 \pm 0.00^{\mathrm{b}}$ \\
Duodenum & $11.18 \pm 1.28^{\mathrm{b}}$ & $0.01 \pm 0.00^{\mathrm{f}}$ & $0.10 \pm 0.01^{\mathrm{d}}$ & $0.93 \pm 0.03^{\mathrm{f}}$ & $0.29 \pm 0.02^{\mathrm{gf}}$ & $\mathrm{ND}$ \\
Lung & $32.42 \pm 2.12^{\mathrm{b}}$ & $0.03 \pm 0.00^{\text {de }}$ & $0.11 \pm 0.01^{\mathrm{d}}$ & $1.72 \pm 0.06^{\mathrm{e}}$ & $0.49 \pm 0.02^{\mathrm{e}}$ & $0.00 \pm 0.00^{\mathrm{b}}$ \\
\hline
\end{tabular}

Means in the same column with different superscripts (a-f) are significantly different $(p<0.05)$.

ND: Not detectable. 
scle tissues. More remarkably, the outcome of our analysis showed that the concentrations of vitamins B in almost chicken by-products were comparable to grain, cereal-grain food and soy-products, which are well recognized as the richest sources of vitamins B (Lebiedzinska and Szefer, 2006). From these findings, it can be said that chicken byproducts, especially liver and heart are particularly good sources of vitamins. The recommended daily allowance (RDA) for an adult male is $1000 \mu \mathrm{g}$ RE vitamin A, $1.2 \mathrm{mg}$ vitamin B1 and $1.4 \mathrm{mg}$ vitamin B2 (Honikel and Schwagele, 2007), therefore, for example; a consuming $5 \mathrm{~g}$ of chicken liver would supply $100 \%$ of vitamin A, and a consuming $100 \mathrm{~g}$ would supply $19.1 \%$ of vitamin B1 and $52 \%$ of vitamin B2. However, it should be noted that vita$\min \mathrm{A}$ is often stored in the body for long periods of time and generally pose a greater risk for toxicity when consumed in excess (Penniston and Tanumihardjo, 2006), therefore, eating a normal and well-balanced diet will not lead to toxicity.

\section{Fatty acid content of chicken by-products}

Since the data concerning the fatty acid composition of edible meat by-products from pork, beef and sheep is available and was reviewed elsewhere (Florek et al., 2012;
Hoffman et al., 2013; Seong et al., 2014a). In contrast, no scientific information regarding the fatty acid composition of chicken by-products is available, therefore, it was complemented with original data obtained in the present study (Table 3 ). The outcome of our analysis revealed that palmitic acid (C16:0) and stearic acid (C18:0), oleic acid (C18:1n-9), linoleic acid (C18:2n-6) and arachidonic acid (C20:4n6) were the most dominant fatty acids detected in all chicken by-products. Dietary n-3 polyunsaturated fatty acids (PUFA) have long been known to have effects on physiological processes such as cardiovascular and immune functions, and neuronal development etc. (Jump, 2002), therefore, there has been much interest in the beneficial effects of these n-3 PUFAs especially linolenic acid (C18:3n-3), eicosapentaenoic acid (C205:n3) and docosahexaenoic acid (C22:5n3) (Burdge and Calder, 2005). Interestingly, the major n-3PUFAs such as C18:3n3, C20:5n3 and C22:6n3 were detected in all chicken by-products examined with relatively high levels. In particular, the levels of C20:5n3 and C22:6n3 were highest in liver, followed by gizzard. Compared with our data, those of Hoffman et al. (2013) found lower $\mathrm{C} 18: 3 \mathrm{n} 3$ and $\mathrm{C} 20: 5 \mathrm{n} 3$ contents and higher $\mathrm{C} 22: 6 \mathrm{n} 3$ content in sheep liver. Similarly Mestre-Prates et al. (2011)

Table 3. Fatty acid profiles (\%) of chicken by-products

\begin{tabular}{|c|c|c|c|c|c|c|c|c|}
\hline Item & Liver & Gizzard & Cecum & Crop & mall intestine & Heart & Duodenum & Lung \\
\hline C14:0 & $0.34 \pm 0.01^{\mathrm{f}}$ & $1.09 \pm 0.02^{b}$ & $1.04 \pm 0.01$ & $54 \pm 0.03^{e}$ & $1.01 \pm 0.01^{b}$ & $0.78 \pm 0.02^{\mathrm{d}}$ & $1.03 \pm 0.01^{\mathrm{bc}}$ & $1.15 \pm 0.01^{\mathrm{a}}$ \\
\hline C16:0 & (1) & & 23.00 & & 25.22 & de & $7^{\mathrm{bcd}}$ & $33.37 \pm 0.26^{\mathrm{a}}$ \\
\hline C16:1n7 & $1.69 \pm 0.06^{\mathrm{e}}$ & -0 & $5.81 \pm 0$ & $2.74 \pm 0.24^{\mathrm{d}}$ & $4.64 \pm 0.13^{\mathrm{bc}}$ & $4.86 \pm 0.12^{\mathrm{bc}}$ & $5.22 \pm 0.18^{\mathrm{b}}$ & $4.43 \pm 0.22^{\mathrm{c}}$ \\
\hline C18:0 & (1) & & & $2^{\mathrm{b}}$ & $8.73 \pm$ & $10.96 \pm 0$ & $8.61 \pm 0.4$ & $9.33 \pm 0.31^{\mathrm{d}}$ \\
\hline C18:1n9 & $.76 \pm 0.74^{\mathrm{e}}$ & $30.61 \pm 0.42^{\mathrm{cd}}$ & $36.72 \pm 0.00^{\mathrm{a}}$ & $8.58 \pm 1.88^{\mathrm{d}}$ & $32.09 \pm 0.26^{\mathrm{c}}$ & $31.40 \pm 1.01^{\mathrm{cd}}$ & $35.14 \pm 0.31^{\mathrm{ab}}$ & $32.95 \pm 0.63^{b c}$ \\
\hline C18:1n7 & $7 \pm 0$ & & $0.08 \pm$ & $6 \pm 0.0$ & $0.07 \pm 0$ & $0.06 \pm 0.0$ & $0.07 \pm 0.01^{\mathrm{a}}$ & $0.06 \pm 0.01^{\mathrm{ab}}$ \\
\hline C18:2n6 & $.12 \pm 0.4 \mathrm{C}$ & $15.60 \pm 0.37^{\mathrm{ab}}$ & $15.92 \pm 0.4$ & $21.06 \pm 4.50^{\mathrm{a}}$ & $17.79 \pm 0.31^{\mathrm{ab}}$ & $20.59 \pm 0.59^{\mathrm{a}}$ & $16.72 \pm 0.37^{\mathrm{ab}}$ & $12.84 \pm 0.13^{b}$ \\
\hline C18:3n6 & $25 \pm 0.0$ & $17+0$ & $0.18 \pm 0.0$ & $13 \pm 0.01^{\mathrm{a}}$ & $0.19 \pm 0.00^{\mathrm{b}}$ & $0.11 \pm 0.00^{\mathrm{a}}$ & $0.18 \pm 0.00^{\mathrm{bc}}$ & $0.14 \pm 0.00^{\mathrm{d}}$ \\
\hline $\mathrm{C} 18$ & & 0.53 & $0.72 \pm($ & $\mathrm{c}^{\mathrm{c}}$ & $0.67 \pm 0$. & $0.59 \pm$ & $0.72 \pm 0$ & 0.57 \\
\hline C20:1 & $0.47 \pm 0$. & $0.46=$ & $0.36 \pm 0$ & $32+0$ & $0.46 \pm 0$. & $0.50 \pm 0$. & $0.42 \pm 0.01^{\mathrm{ab}}$ & $0.45 \pm 0.01^{\mathrm{ab}}$ \\
\hline C20:4n6 & & & & & & & & \\
\hline $\mathrm{C} 20: 5 \mathrm{n} 3$ & $4 \pm 0$ & $0.16 \pm$ & $0.18 \pm 0$ & $0.18 \pm 0$ & $0.22 \pm 0.01^{\mathrm{b}}$ & $0.17 \pm 0$. & $0.14 \pm 0.00^{\mathrm{c}}$ & $0.17 \pm 0.02^{\mathrm{c}}$ \\
\hline $\mathrm{C} 22: 4 \mathrm{n} 6$ & \pm 0 & $3^{a}$ & 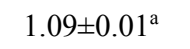 & & $1.24 \pm$ & $0.25 \pm 0.02^{\mathrm{d}}$ & 0.7 & $0.49 \pm 0.06^{\mathrm{c}}$ \\
\hline $\mathrm{C} 22: 6 \mathrm{n} 3$ & $0 \pm 0.08^{\mathrm{a}}$ & $0.35 \pm 0$ & $0.12 \pm 0.12^{\mathrm{de}}$ & $0.08 \pm 0.02^{\mathrm{de}}$ & $0.29 \pm 0.05^{\text {bc }}$ & $0.06 \pm 0.00^{\mathrm{e}}$ & $0.27 \pm 0.02^{\mathrm{bc}}$ & $0.20 \pm 0.02^{\mathrm{cd}}$ \\
\hline SFA & $96+0$ & $39.44 \pm$ & $31.82 \pm$ & $40.02 \pm$ & $34.97 \pm 0$ & $36.01 \pm 0$ & $\pm 1.06^{\mathrm{c}}$ & $43.85 \pm 0.52^{\mathrm{a}}$ \\
\hline UFA & $.04 \pm 0.24^{\mathrm{d}}$ & $60.56 \pm 0$ & $68.19 \pm 0.73^{\mathrm{a}}$ & $59.98 \pm 2.2^{\mathrm{c}}$ & $65.03 \pm 0.46^{\mathrm{ab}}$ & $63.99 \pm 0.45^{\mathrm{b}}$ & $64.45 \pm 1.06^{\mathrm{b}}$ & $56.15 \pm 0.52^{\mathrm{d}}$ \\
\hline MUFA & $23.98 \pm 0.76^{\mathrm{e}}$ & $35.61 \pm$ & $42.97 \pm 0.02^{\mathrm{a}}$ & $31.70 \pm 2.13^{\mathrm{d}}$ & $37.26 \pm 0.21^{\mathrm{c}}$ & $36.82 \pm 0.94^{\mathrm{c}}$ & $40.85 \pm 0.44^{\mathrm{ab}}$ & $37.89 \pm 0.83^{b c}$ \\
\hline PUFA & $32.05 \pm 0.76^{\mathrm{a}}$ & $24.94 \pm 0.71^{\mathrm{b}}$ & $25.22 \pm 0.75^{\mathrm{b}}$ & $28.28 \pm 4.29^{\mathrm{ab}}$ & $27.78 \pm 0.46^{\mathrm{ab}}$ & $27.17 \pm 1.05^{\mathrm{ab}}$ & $23.61 \pm 0.65^{\mathrm{bc}}$ & $18.27 \pm 0.36^{\mathrm{c}}$ \\
\hline$n-3$ & $2.41 \pm 0.1^{\mathrm{a}}$ & $1.04 \pm 0.03^{\mathrm{bcd}}$ & $1.01 \pm 0.09^{\mathrm{cd}}$ & $0.64 \pm 0.01^{\mathrm{f}}$ & $1.17 \pm 0.02^{\mathrm{b}}$ & $0.82 \pm 0.01^{\mathrm{e}}$ & $1.14 \pm 0.04^{\mathrm{bc}}$ & $0.94 \pm 0.02^{\mathrm{de}}$ \\
\hline$n-6$ & $29.64 \pm 0.69^{\mathrm{a}}$ & $23.90 \pm 0.69^{\mathrm{ab}}$ & $24.20 \pm 0.84^{\mathrm{ab}}$ & $27.64 \pm 4.30^{\mathrm{ab}}$ & $26.61 \pm 0.47^{\mathrm{ab}}$ & $26.36 \pm 1.04^{\mathrm{ab}}$ & $22.47 \pm 0.61^{\mathrm{bc}}$ & $17.33 \pm 0.35^{\mathrm{c}}$ \\
\hline $\mathrm{n} 6 / \mathrm{n} 3$ & $.35 \pm 0.39^{\mathrm{d}}$ & $22.92 \pm 0.44^{\mathrm{c}}$ & $24.22 \pm 3.05^{\mathrm{bc}}$ & $43.59 \pm 7.08^{\mathrm{a}}$ & $22.75 \pm 0.78^{\mathrm{c}}$ & $32.17 \pm 1.15^{\mathrm{b}}$ & $19.76 \pm 0.23^{\mathrm{c}}$ & $18.51 \pm 0.27^{\mathrm{cd}}$ \\
\hline & $0.54 \pm 0.02^{\mathrm{f}}$ & $0.90 \pm($ & $1.35 \pm 0.03^{\mathrm{a}}$ & $0.79 \pm 0.02^{\mathrm{e}}$ & $1.07 \pm 0.02^{\mathrm{bc}}$ & $1.02 \pm 0.03^{\mathrm{c}}$ & $1.15 \pm 0.05^{\mathrm{b}}$ & $0.87 \pm 0.03^{\mathrm{de}}$ \\
\hline PUFA/SFA & $0.73 \pm 0.02^{\mathrm{a}}$ & $0.63 \pm 0.03^{\mathrm{a}}$ & $0.79 \pm 0.04^{\mathrm{a}}$ & $0.73 \pm 0.13^{\mathrm{a}}$ & $0.8 \pm 0.02^{\mathrm{a}}$ & $0.76 \pm 0.03^{\mathrm{a}}$ & $0.67 \pm 0.04^{\mathrm{a}}$ & $0.42 \pm 0.01^{\mathrm{b}}$ \\
\hline
\end{tabular}

Means in the same row with different superscripts (a-f) are significantly different $(p<0.05)$.

SFA, saturated fatty acid; UFA, unsaturated fatty acid; MUFA, monounsaturated fatty acid; PUFA, polyunsaturated fatty acid. 
reported lower $\mathrm{C} 18: 3 \mathrm{n} 3$ and $\mathrm{C} 20: 5 \mathrm{n} 3$ contents in beef liver. On the other hand, when compared to the $\mathrm{C} 18: 3 \mathrm{n} 3$, $\mathrm{C} 20: 5 \mathrm{n} 3$ and $\mathrm{C} 22: 6 \mathrm{n} 3$ contents in muscle tissues from pork and beef species (Alonso et al., 2012; Ba et al., 2013; Costa et al., 2008; Honikel, 2011), most of chicken byproducts examined had higher levels of these fatty acids.

Total saturated fatty acids (SFA), unsaturated fatty acids (UFA), polyunsaturated fatty acids (PUFA) levels ranged between the by-products from $31.82 \%$ to $43.96 \%, 56.04 \%$ to $68.19 \%$, and $18.27 \%$ to $32.05 \%$, respectively in the present study. Amongst, liver had the highest total PUFAs level, followed by gizzard and lung $(p<0.05)$. More remarkably, most of chicken by-products examined had lower total SFA levels whereas had higher total UFAs and PUFAs levels compared with those in meat by-products as well as muscle tissues from sheep, pork and beef (Ba et al., 2013; Hoffman et al., 2013; Jung et al., 2011; Mestre-Prates et al., 2011).

The consumption of dietary fats has long been associated to chronic pathologies such as obesity, diabetes and cardiovascular disease etc. Thus, the recommendation of Food and Agriculture Organization (FAO) and World Health Organization (WHO) for adult humans includes the intakes of $20-35 \%$ of diet energy of total fat, less than $10 \%$ of SFA, $15-20 \%$ of MUFA and $6-11 \%$ of PUFA (Burlingame et al., 2009); therefore, reducing the intake of SFAs and increasing the intake of PUFAs are strongly encouraged. Also, the recommendations for the PUFA/ SFA ratio for the healthy diet as a whole should be 0.40 or higher, while the ratio of $n-6 / n-3$ fatty acids should be 4.0 or lower (Department of Health, 1994). According to the outcome of our analysis, the PUFA/SFA ratios in all of chicken by-products examined were above the recommended value of 0.4 . Unfortunately, however, the $n-6 / n-3$ ratios in all of chicken by-products examined were above the recommended values of less than 4.0 in the present study. Similar to our results, a great number of studies also found that the $n-6 / n-3$ ratios in offal and muscle tissues of most of animal species studied were generally higher than the recommended values of less than 4.0 (Alonso et al., 2012; Ba et al., 2013; Seong et al., 2014b; Wood et al., 2003). On the other hand, cholesterol is well known as an essential part of adequate body function, forming an important component of steroid hormones, vitamins and bile acids. However, high cholesterol intake has been associated with an elevated risk of cardiovascular diseases such as coronary heart disease and high blood pressure as well as diabetes (Kratz, 2005). The cholesterol content in meat and meat by-products as a whole therefore becomes one of the concerns by consumers, and the recommended maximum cholesterol intake is $300 \mathrm{mg}$ per day (American Heart Association, 2008). Although the cholesterol con-

Table 4. Amino acid composition (\%) of chicken by-products

\begin{tabular}{|c|c|c|c|c|c|c|c|c|}
\hline Item & Liver & $\overline{\text { Gizzard }}$ & Cecum & Crop & Small intestine & "Heart & Duodenum & Lung \\
\hline \multicolumn{9}{|c|}{ Essential amino acids (EA) } \\
\hline THR & $0.79 \pm 0.01^{\mathrm{a}}$ & $0.76 \pm 0.01^{\mathrm{ab}}$ & $0.51 \pm 0.03^{\mathrm{d}}$ & $0.74 \pm 0.01^{b}$ & $0.53 \pm 0.01^{\mathrm{d}}$ & $0.63 \pm 0.01^{\mathrm{c}}$ & $0.53 \pm 0.01^{\mathrm{d}}$ & $0.46 \pm 0.01^{\mathrm{e}}$ \\
\hline MET & $0.38 \pm 0.00^{\mathrm{a}}$ & $0.40 \pm 0.00^{\mathrm{a}}$ & $0.27 \pm 0.01^{\mathrm{c}}$ & $0.35 \pm 0.01^{\mathrm{b}}$ & $0.26 \pm 0.00^{\mathrm{c}}$ & $0.34 \pm 0.01^{\mathrm{b}}$ & $0.26 \pm 0.01^{\mathrm{c}}$ & $0.18 \pm 0.01^{\mathrm{d}}$ \\
\hline VAL & $0.83 \pm 0.01^{\mathrm{a}}$ & $0.69 \pm 0.01^{\mathrm{c}}$ & $0.49 \pm 0.02^{\mathrm{e}}$ & $0.74 \pm 0.01^{\mathrm{b}}$ & $0.52 \pm 0.01^{\mathrm{e}}$ & $0.62 \pm 0.00^{\mathrm{d}}$ & $0.53 \pm 0.01^{\mathrm{e}}$ & $0.50 \pm 0.02^{\mathrm{e}}$ \\
\hline LEU & $1.41 \pm 0.01^{\mathrm{a}}$ & $1.27 \pm 0.02^{\mathrm{b}}$ & $0.87 \pm 0.04^{\mathrm{de}}$ & $1.21 \pm 0.01^{\mathrm{b}}$ & $0.90 \pm 0.01^{\mathrm{d}}$ & $1.14 \pm 0.01^{\mathrm{c}}$ & $0.91 \pm 0.02^{\mathrm{d}}$ & $0.82 \pm 0.02^{\mathrm{e}}$ \\
\hline ILE & $0.65 \pm 0.01^{\mathrm{a}}$ & $0.61 \pm 0.01^{\mathrm{b}}$ & $0.42 \pm 0.02^{\mathrm{d}}$ & $0.61 \pm 0.01^{\mathrm{b}}$ & $0.44 \pm 0.00^{\mathrm{d}}$ & $0.53 \pm 0.01^{\mathrm{c}}$ & $0.44 \pm 0.01^{\mathrm{d}}$ & $0.35 \pm 0.01^{\mathrm{e}}$ \\
\hline HIS & $0.43 \pm 0.00^{\mathrm{a}}$ & $0.37 \pm 0.00^{\mathrm{b}}$ & $0.24 \pm 0.01^{\mathrm{e}}$ & $0.35 \pm 0.00^{\mathrm{b}}$ & $0.26 \pm 0.00^{\mathrm{de}}$ & $0.32 \pm 0.00^{\mathrm{c}}$ & $0.26 \pm 0.01^{\mathrm{d}}$ & $0.28 \pm 0.00^{\mathrm{d}}$ \\
\hline PHE & $0.76 \pm 0.02^{\mathrm{a}}$ & $0.66 \pm 0.01^{\mathrm{c}}$ & $0.47 \pm 0.02^{\mathrm{e}}$ & $0.73 \pm 0.01^{\mathrm{b}}$ & $0.48 \pm 0.01^{\mathrm{e}}$ & $0.60 \pm 0.01^{\mathrm{d}}$ & $0.49 \pm 0.01^{\mathrm{e}}$ & $0.41 \pm 0.01^{\mathrm{f}}$ \\
\hline LYS & $1.34 \pm 0.01^{\mathrm{a}}$ & $1.25 \pm 0.02^{\mathrm{b}}$ & $0.84 \pm 0.05^{\mathrm{de}}$ & $1.14 \pm 0.01^{\mathrm{c}}$ & $0.89 \pm 0.01^{\mathrm{d}}$ & $1.15 \pm 0.01^{\mathrm{c}}$ & $0.91 \pm 0.02^{\mathrm{d}}$ & $0.79 \pm 0.01^{\mathrm{e}}$ \\
\hline$\Sigma$ EA & $.60 \pm 0.41^{\mathrm{a}}$ & $6.02 \pm 0.35^{\mathrm{ab}}$ & $4.12 \pm 0.30^{\mathrm{bc}}$ & $5.86 \pm 0.28^{\mathrm{b}}$ & $4.27 \pm 0.25^{\mathrm{bc}}$ & $5.32 \pm 0.31^{\mathrm{b}}$ & $6.60 \pm 0.48^{\mathrm{a}}$ & $3.78 \pm 0.22^{\mathrm{c}}$ \\
\hline \multicolumn{9}{|c|}{ Non-essential amino acid (NE) } \\
\hline$\overline{\mathrm{ALA}}$ & $0.98 \pm 0.01^{\mathrm{a}}$ & $0.99 \pm 0.02^{\mathrm{a}}$ & $0.66 \pm 0.03^{\mathrm{d}}$ & $0.84 \pm 0.01^{b}$ & $0.68 \pm 0.01^{\mathrm{d}}$ & $0.77 \pm 0.01^{\mathrm{c}}$ & $0.68 \pm 0.01^{\mathrm{d}}$ & $0.65 \pm 0.02^{\mathrm{d}}$ \\
\hline ARG & $1.04 \pm 0.01^{\mathrm{b}}$ & $1.16 \pm 0.02^{\mathrm{a}}$ & $0.75 \pm 0.04^{\mathrm{e}}$ & $0.93 \pm 0.01^{\mathrm{c}}$ & $0.80 \pm 0.01^{\mathrm{e}}$ & $0.85 \pm 0.01^{\mathrm{d}}$ & $0.80 \pm 0.02^{\mathrm{e}}$ & $0.65 \pm 0.01^{\mathrm{f}}$ \\
\hline ASP & $1.49 \pm 0.01^{\mathrm{a}}$ & $1.50 \pm 0.02^{\mathrm{a}}$ & $1.00 \pm 0.05^{\mathrm{d}}$ & $1.40 \pm 0.02^{\mathrm{b}}$ & $1.03 \pm 0.01^{\mathrm{d}}$ & $1.24 \pm 0.02^{\mathrm{c}}$ & $1.04 \pm 0.02^{\mathrm{d}}$ & $0.87 \pm 0.02^{\mathrm{e}}$ \\
\hline CYS & $0.27 \pm 0.00^{\mathrm{a}}$ & $0.20 \pm 0.00^{\mathrm{b}}$ & $0.16 \pm 0.01^{\mathrm{e}}$ & $0.21 \pm 0.00^{\mathrm{b}}$ & $0.15 \pm 0.00^{\mathrm{d}}$ & $0.18 \pm 0.00^{\mathrm{c}}$ & $0.16 \pm 0.00^{\mathrm{d}}$ & $0.14 \pm 0.01^{\mathrm{e}}$ \\
\hline GLU & $2.23 \pm 0.02^{\mathrm{b}}$ & $2.73 \pm 0.05^{\mathrm{a}}$ & $1.66 \pm 0.09^{\mathrm{d}}$ & $1.98 \pm 0.03^{\mathrm{c}}$ & $1.66 \pm 0.02^{\mathrm{d}}$ & $2.03 \pm 0.03^{\mathrm{c}}$ & $1.66 \pm 0.04^{\mathrm{d}}$ & $1.32 \pm 0.03^{\mathrm{e}}$ \\
\hline GLY & $0.81 \pm 0.01^{\mathrm{c}}$ & $1.15 \pm 0.02^{\mathrm{a}}$ & $0.74 \pm 0.03^{\mathrm{de}}$ & $0.98 \pm 0.03^{\mathrm{b}}$ & $0.78 \pm 0.01^{\mathrm{cd}}$ & $0.69 \pm 0.01^{\mathrm{e}}$ & $0.78 \pm 0.02^{\mathrm{cd}}$ & $0.72 \pm 0.03^{\mathrm{de}}$ \\
\hline PRO & $0.71 \pm 0.01^{\mathrm{b}}$ & $0.82 \pm 0.02^{\mathrm{a}}$ & $0.59 \pm 0.02^{\text {cd }}$ & $0.72 \pm 0.01^{\mathrm{b}}$ & $0.58 \pm 0.01^{\mathrm{cd}}$ & $0.61 \pm 0.01^{\mathrm{c}}$ & $0.61 \pm 0.01^{\mathrm{c}}$ & $0.55 \pm 0.02^{\mathrm{d}}$ \\
\hline SER & $0.80 \pm 0.00^{\mathrm{a}}$ & $0.77 \pm 0.01^{\mathrm{a}}$ & $0.53 \pm 0.03^{\mathrm{c}}$ & $0.78 \pm 0.01^{\mathrm{a}}$ & $0.55 \pm 0.01^{\mathrm{c}}$ & $0.60 \pm 0.01^{b}$ & $0.56 \pm 0.01^{\mathrm{c}}$ & $0.49 \pm 0.01^{\mathrm{d}}$ \\
\hline TYR & $0.59 \pm 0.01^{\mathrm{b}}$ & $0.56 \pm 0.01^{\mathrm{b}}$ & $0.40 \pm 0.02^{\mathrm{d}}$ & $0.62 \pm 0.01^{\mathrm{a}}$ & $0.41 \pm 0.01^{\mathrm{d}}$ & $0.48 \pm 0.00^{\mathrm{c}}$ & $0.41 \pm 0.01^{\mathrm{d}}$ & $0.29 \pm 0.00^{\mathrm{e}}$ \\
\hline$\Sigma \mathrm{NE}$ & $8.92 \pm 0.51^{\mathrm{a}}$ & $9.88 \pm 0.47^{\mathrm{a}}$ & $6.48 \pm 0.34^{\mathrm{bc}}$ & $8.47 \pm 0.44^{\mathrm{ab}}$ & $6.63 \pm 0.39^{b}$ & $6.69 \pm 0.34^{b}$ & $6.69 \pm 0.46^{\mathrm{b}}$ & $5.68 \pm 0.26^{\mathrm{c}}$ \\
\hline $\mathrm{EA} / \mathrm{AA}$ & $42.52 \pm 2.89^{\mathrm{b}}$ & $37.86 \pm 3.11^{\mathrm{c}}$ & $38.86 \pm 1.92^{\mathrm{c}}$ & $40.89 \pm 2.55^{\mathrm{ab}}$ & $39.17 \pm 2.74^{\mathrm{bc}}$ & $44.29 \pm 3.31^{\mathrm{a}}$ & $49.66 \pm 3.88^{\mathrm{a}}$ & $39.93 \pm 1.36^{\mathrm{bc}}$ \\
\hline
\end{tabular}

Means in the same row with different superscripts (a-f) are significantly different $(p<0.05)$. 
tent in chicken by-products were not measured in the present study, however, it should be noted that animal's organs as a whole have relatively higher cholesterol content (Ockerman and Basu, 2004), therefore should be eaten reasonably.

\section{Amino acid content of chicken by-products}

The amino acid (AA) contents of chicken by-products are shown in Table 4. Our results depict that seven-teen amino acids including essential amino acids (EAA) and non-essential amino acids (NE) with different levels were found. All of eight major EAAs including; threonine (THR), methionine (MET), valine (VAL), isoleucine (ILEU), leucine (LEU), histidine (HIS), phynylalanine (PHE) and lysine (LYS) were detected in all of by-products examined. LEU and LYS were the most dominant EAAs detected. Among the by-products examined, liver contained the highest levels of most of EAAs, followed by gizzard and heart $(p<0.05)$. EAA cannot be produced by the human body, thus they must be supplied by diet. Without these essential amino acids, the body is unable to function normally, also the presence of amino acids enables vitamins and minerals to perform all their physiological functions (Wu, 2010). In the present study, heart and duodenum had the highest total essential amino acids/total amino acids (EAAs/AA) ratio, followed by liver $(p<0.05)$. Edible meat by-products have been found to be a source of important nutrients like essential amino acids and among them proteins of the internal organs have high biological value (Savaran and Pavlava, 1980) with a balanced EAA content similar to that of muscle proteins (Aristoy and Toldra,
2011). When compared to the total EAAs/AA ratio in pork liver (42\%) reported in literature (Kim et al., 2008), the chicken liver had similar total EAA contents but slightly lower than those of beef liver (47.41\%) (Seong et al., $2014 b$ ). Importantly, it was reported that the levels of EAAs in meat by-products are not remarkably diminished after cooking or heating treatment due to the low-reducing sugar content of these by-products does not cause secondary degradation reactions such as the Maillard reaction (Aristoy and Toldra, 2011). From our observations, it can be said that the chicken by-products examined are good sources of EAAs. Additionally, we also assume that the differences in levels and quality of EAs contents may be attributed due to the differences in protein types (e.g., collagen, myofibril protein etc) between the by-products. For the NEs, even if they can be produced by the human body, it is mandatory to have all the raw materials necessary for their production therefore, inadequate consumption of amino acids, the primary units of proteins, can lead to protein malnutrition.

\section{Mineral content of chicken by-products}

The concentrations of minerals found in chicken byproducts are summarized in Table 5. In general, the mineral contents significantly differed between the by-products examined. Among the macro-elements detected, the concentrations of phosphorous $(\mathrm{P})$ were generally higher than others, followed by (in decreasing order) potassium $(\mathrm{K})$, sodium $(\mathrm{Na})$, magnesium $(\mathrm{Mg})$ and calcium $(\mathrm{Ca})$. Liver had higher amounts of $\mathrm{K}, \mathrm{Na}$ and $\mathrm{P}$, while cecum and crop had higher amount of $\mathrm{Ca}$ and $\mathrm{Mg}$, respectively

Table 5. Mineral content of chicken by-products (mg/kg)

\begin{tabular}{|c|c|c|c|c|c|c|c|c|c|}
\hline \multirow{2}{*}{ Item } & \multicolumn{5}{|c|}{ Marco-element } & \multicolumn{4}{|c|}{ Trace-element } \\
\hline & $\mathrm{K}$ & $\mathrm{Na}$ & $\mathrm{Ca}$ & $\mathrm{Mg}$ & $P$ & $\mathrm{Fe}$ & $\mathrm{Cu}$ & $\mathrm{Mn}$ & $\mathrm{Zn}$ \\
\hline Liver & $\begin{array}{c}2,914.38 \\
\pm 94.72^{\mathrm{a}}\end{array}$ & $\begin{array}{l}1,034.00 \\
\pm 39.95^{\mathrm{a}}\end{array}$ & $\begin{array}{c}89.26 \\
\pm 3.44^{\mathrm{d}}\end{array}$ & $\begin{array}{l}217.12 \\
\pm 7.56^{\mathrm{b}}\end{array}$ & $\begin{array}{c}2,934.46 \\
\pm 87.92^{\mathrm{a}}\end{array}$ & $\begin{array}{c}79.29 \\
\pm 1.96^{\mathrm{a}}\end{array}$ & $\begin{array}{c}3.67 \\
\pm 0.22^{\mathrm{a}}\end{array}$ & $\begin{array}{c}2.51 \\
\pm 0.13^{\mathrm{a}}\end{array}$ & $\begin{array}{c}29.91 \\
\pm 3.64^{\mathrm{a}}\end{array}$ \\
\hline Gizzard & $\begin{array}{l}2,408.43 \\
\pm 26.46^{\mathrm{bc}}\end{array}$ & $\begin{array}{c}947.71 \\
\pm 36.32^{\mathrm{ab}}\end{array}$ & $\begin{array}{l}117.44 \\
\pm 7.54^{\mathrm{c}}\end{array}$ & $\begin{array}{l}168.24 \\
\pm 6.92^{\mathrm{de}}\end{array}$ & $\begin{array}{l}1,661.59 \\
\pm 27.04^{\mathrm{de}}\end{array}$ & $\begin{array}{c}16.51 \\
\pm 0.69^{\mathrm{e}}\end{array}$ & $\begin{array}{c}1.73 \\
\pm 0.14^{\mathrm{d}}\end{array}$ & $\begin{array}{c}1.25 \\
\pm 0.03^{\mathrm{c}}\end{array}$ & $\begin{array}{c}26.01 \\
\pm 0.57^{\mathrm{ab}}\end{array}$ \\
\hline Cecum & $\begin{array}{c}1,210.24 \\
\pm 191.75^{\mathrm{ef}}\end{array}$ & $\begin{array}{c}443.43 \\
\pm 59.02^{\mathrm{e}}\end{array}$ & $\begin{array}{l}200.21 \\
\pm 7.54^{\mathrm{a}}\end{array}$ & $\begin{array}{l}179.74 \\
\pm 9.82^{\text {cd }}\end{array}$ & $\begin{array}{l}1,431.23 \\
\pm 142.94^{\mathrm{f}}\end{array}$ & $\begin{array}{c}18.64 \\
\pm 1.81^{\mathrm{de}}\end{array}$ & $\begin{array}{c}2.64 \\
\pm 0.12^{\mathrm{bc}}\end{array}$ & $\begin{array}{c}1.55 \\
\pm 0.22^{\mathrm{b}}\end{array}$ & $\begin{array}{c}22.37 \\
\pm 0.87^{\mathrm{bc}}\end{array}$ \\
\hline Crop & $\begin{array}{c}2,540.12 \\
\pm 95.06^{\mathrm{b}}\end{array}$ & $\begin{array}{c}858.56 \\
\pm 28.37^{\mathrm{b}}\end{array}$ & $\begin{array}{l}125.99 \\
\pm 3.08^{\mathrm{bc}}\end{array}$ & $\begin{array}{l}291.30 \\
\pm 9.84^{\mathrm{a}}\end{array}$ & $\begin{array}{c}2,716.85 \\
\pm 52.32^{\mathrm{b}}\end{array}$ & $\begin{array}{c}37.15 \\
\pm 1.64^{\mathrm{c}}\end{array}$ & $\begin{array}{c}2.83 \\
\pm 0.10^{\mathrm{b}}\end{array}$ & $\begin{array}{c}1.74 \\
\pm 0.02^{\mathrm{b}}\end{array}$ & $\begin{array}{c}21.69 \\
\pm 0.82^{\mathrm{bc}}\end{array}$ \\
\hline Small intestine & $\begin{array}{l}1,176.14 \\
\pm 58.90^{f}\end{array}$ & $\begin{array}{c}414.22 \\
\pm 16.04^{\mathrm{e}}\end{array}$ & $\begin{array}{l}135.07 \\
\pm 7.21^{\mathrm{bc}}\end{array}$ & $\begin{array}{c}159.04 \\
\pm 12.73^{\text {def }}\end{array}$ & $\begin{array}{l}1,469.76 \\
\pm 41.02^{\mathrm{ef}}\end{array}$ & $\begin{array}{l}23.35 \\
\pm 2.07^{\mathrm{d}}\end{array}$ & $\begin{array}{c}1.32 \\
\pm 0.05^{\mathrm{d}}\end{array}$ & $\begin{array}{c}1.00 \\
\pm 0.03^{\text {cd }}\end{array}$ & $\begin{array}{c}20.09 \\
\pm 1.13^{\mathrm{c}}\end{array}$ \\
\hline Heart & $\begin{array}{l}2,140.37 \\
\pm 50.48^{c}\end{array}$ & $\begin{array}{c}947.21 \\
\pm 31.54^{\mathrm{ab}}\end{array}$ & $\begin{array}{c}90.22 \\
\pm 5.56^{\mathrm{d}}\end{array}$ & $\begin{array}{l}196.45 \\
\pm 5.18^{\mathrm{bc}}\end{array}$ & $\begin{array}{l}1,944.31 \\
\pm 34.02^{\mathrm{c}}\end{array}$ & $\begin{array}{c}32.99 \\
\pm 0.87^{\mathrm{c}}\end{array}$ & $\begin{array}{c}2.23 \\
\pm 0.10^{\mathrm{c}}\end{array}$ & $\begin{array}{c}0.67 \\
\pm 0.03^{\mathrm{e}}\end{array}$ & $\begin{array}{c}23.22 \\
\pm 1.09^{\mathrm{bc}}\end{array}$ \\
\hline Duodenum & $\begin{array}{c}1,496.03 \\
\pm 129.61^{\mathrm{de}}\end{array}$ & $\begin{array}{c}548.80 \\
\pm 33.71^{\mathrm{d}}\end{array}$ & $\begin{array}{l}123.16 \\
\pm 8.76^{\mathrm{c}}\end{array}$ & $\begin{array}{l}153.59 \\
\pm 4.07^{\text {ef }}\end{array}$ & $\begin{array}{l}1,697.03 \\
\pm 71.34^{\mathrm{d}}\end{array}$ & $\begin{array}{c}33.36 \\
\pm 3.97^{\mathrm{c}}\end{array}$ & $\begin{array}{c}1.63 \\
\pm 0.06^{\mathrm{d}}\end{array}$ & $\begin{array}{c}1.09 \\
\pm 0.02^{\text {cd }}\end{array}$ & $\begin{array}{l}21.08 \\
\pm 0.73^{\mathrm{c}}\end{array}$ \\
\hline Lung & $\begin{array}{l}1,752.09 \\
\pm 40.67^{\mathrm{d}}\end{array}$ & $\begin{array}{c}753.91 \\
\pm 19.85^{\mathrm{c}}\end{array}$ & $\begin{array}{l}146.05 \\
\pm 7.74^{\mathrm{b}}\end{array}$ & $\begin{array}{l}136.15 \\
\pm 6.87^{\mathrm{f}}\end{array}$ & $\begin{array}{l}1,936.93 \\
\pm 25.21^{\mathrm{c}}\end{array}$ & $\begin{array}{c}59.59 \\
\pm 2.52^{\mathrm{b}}\end{array}$ & $\begin{array}{c}1.75 \\
\pm 0.29^{\mathrm{d}}\end{array}$ & $\begin{array}{c}0.88 \\
\pm 0.06^{\mathrm{de}}\end{array}$ & $\begin{array}{c}14.26 \\
\pm 0.47^{\mathrm{d}}\end{array}$ \\
\hline
\end{tabular}

Means in the same column with different superscripts (a-f) are significantly different $(p<0.05)$. 
in comparison with other remaining by-products $(p<0.05)$. Compared with our data, those of Florek et al. (2012) reported higher amounts of $\mathrm{K}, \mathrm{P}$ and $\mathrm{Mg}$ in beef liver and heart. Especially, the amounts of $\mathrm{Ca}$ in liver, heart and lung were generally higher compared with those reported for the pork by-products (Seong et al., 2014a) and also higher than the Ca contents $(19.9-87 \mathrm{mg} / \mathrm{kg})$ in muscle tissues from rabbit, rhea and beef origins (Hermida et al., 2006; Honikel, 2011; Ramos et al., 2012).

Among the minerals often found in foods, iron (Fe), manganese $(\mathrm{Mn})$, zinc $(\mathrm{Zn})$ and copper $(\mathrm{Cu})$ are grouped as trace elements that are vital for maintaining human health, insufficient intake of these trace minerals can cause symptoms of nutritional deficiency (Tapiero and Tew, 2003). In nutritional terms, the interest of meat by-products lies on their provision of proteins, vitamins and minerals. The outcome of our analysis showed that liver had the highest $\mathrm{Fe}, \mathrm{Cu}, \mathrm{Mn}$ and $\mathrm{Zn}$ contents. Fe is one of the vital minerals needed for the optimum function of blood; iron deficiency causes anemia, especially in pregnant women and children (Benoist, 2001). When compared to the Fe levels in beef liver (29.3-66.71 mg/kg) (Florek et al., 2012; Seong et al., 2014b), the chicken liver had higher Fe content. More remarkably, when compared to the Fe levels in breast chicken $(5 \mathrm{mg} / \mathrm{kg})$, beef steaks $(14 \mathrm{mg} / \mathrm{kg})$, pork chop $(13 \mathrm{mg} / \mathrm{kg})$, duck meat $(24 \mathrm{mg} / \mathrm{kg})$ and mutton meat $(17 \mathrm{mg} / \mathrm{kg}$ ) reported by Pereira and Vicente (2013), most of chicken by-products had considerably higher amounts of $\mathrm{Fe}$ content. More importantly, the iron in internal organs (e.g., liver and heart etc.) is heme iron whose absorption into the intestinal lumen is several times greater than non-heme iron present in other foods (Hallberg and Hulthén, 2000; Simpson and McKie, 2009).

Similarly, the Zn contents in all chicken by-products were much higher compared with those in most of edible meat by-products and muscle tissues from various animal species as cited above. Similarly, $\mathrm{Mn}$ is an essential mineral involved the growth, metabolism and enzymatic defense systems of the body (Aschner and Aschner, 2005). The levels of $\mathrm{Mn}$ in chicken by-products were comparable to those in meat by-products from other species and higher than those in muscle tissues (Honikel, 2011). From these obtained results, it can be said that chicken by-products are particularly good sources of essential trace minerals.

\section{Conclusion}

This paper studied majority of chicken by-products in terms of proximate (e.g., protein, fat, moisture and calories) and nutritional compositions (e.g., vitamin, mineral, fatty acid and amino acid). Based on the obtained results, it is concluded that the proximate and nutritional compositions widely varied among the by-products examined. Liver and gizzard are the richest sources of protein comparable to the protein levels in some muscle tissues. Additionally, liver contained higher amounts of all vitamins compared with those in other remaining by-products examined. Furthermore, most of chicken by-products had lower total SFA levels and higher total UFAs and PUFAs levels compared with those in meat by-products as well as muscle tissues reported in literature. More remarkably, all of by-products showed desirable PUFA/SFA and EAA/ AA ratios. This is the first study of comprehensive information about chicken by-products; therefore, the data of the present study provide not only the useful information to consumers and processors but also the important databases for further investigations.

\section{Acknowledgements}

This work was supported by "Cooperative Research Program for Agriculture Science \&Technology Development (Project No. PJ90697402)" Rural Development Administration, Republic of Korea.

\section{References}

1. Alonso, V., Najes, L. M., Provincial, L., Guillen, E., Gil, M., Roncales, P., and Beltran, J. A. (2012) Influence of dietary fat on pork eating quality. Meat Sci. 92, 366-373.

2. American Heart Association. (2008) Heart and Stroke Encyclopedia. Dietary Guidelines for Healthy American Adults. Cholesterol. Fat. Retrieved September 13, 2008 from World Wide Web: http://www.americanheart.org.

3. AOAC (2000) Official methods of analysis of the AOAC 986.15 Multi-element method. 17th ed, Arlington, Virginia, USA, pp. 1-8.

4. Aristoy, M. C. and Toldra, F. (2011) Essential amino acids. In: Handbook of Analysis of Edible Animal By-Products. Nollet, L. M. L. and Toldrá, F (eds) CRC Press, Boca Raton, FL, USA, pp. 123-135.

5. Aschner, J. L. and Aschner M. (2005) Nutritional aspects of manganese homeostasis. Mol. Aspects Med. 26, 353-362.

6. Ba, H. V., Ryu, K. S., Nguyen, T. K. L., and Hwang, I. H. (2013) Influence of particular breed on meat quality parameters, sensory characteristics and volatile compounds. Food Sci. Biotechnol. 22, 651-658.

7. Benoist, B. (2001) Deficiency anemia: Reexamining the nature and magnitude of the public health problem. Introduction. Nutrition 131, 564S. 
8. Bonoli, M., Caboni, M. F., Rodriguez-Estrada, M. T., and Lercker, G. (2007) Effect of feeding fat sources on the quality and composition of lipids of precooked ready-to-eat fried chicken patties. Food Chem. 101, 1327-1337.

9. Bray, G. A., Paeratakul, S., and Popkin, B. M. (2004) Dietary fat and obesity: a review of animal, clinical and epidemiological studies. Physio. Behav. 83, 549-555.

10. Burdge, G. C. and Calder, P. C. (2005) Alpha-linolenic acid metabolism in adult humans: the effects of gender and age on conversion to longer-chain polyunsaturated fatty acids. Uer. J. Lipid Sci. Technol. 107, 426-439.

11. Burlingame, B., Nishida, C., Uauy, R., and Weisell, R. (2009) Fats and fatty acids in human nutrition (Report of a joint FAO/ WHO Export Consultation, November, 2008). Ann. Nutr. Metab. 55, 1-380.

12. Choi, Y. S., Park, K. S., Choi, J. H., Kim, H. W., Song, D. H., Kim, J. M., Chung, H. J., and Kim, C. J. (2010) Physico-chemical properties of chicken meat emulsion systems with dietary fiber extracted from makgeolli Lees. Korean J. Food Sci. An. 30, 910-917.

13. Costa, P., Roseiro, L. C., Bessa, R. J. B, Padilha, M., Partidario, A., Marques de Almeida, J., Calkins, C. R., and Santos, C. (2008) Muscle fiber and fatty acid profiles of MertolengaPDO meat. Meat Sci. 78, 502-512.

14. Department of Health. (1994) Nutritional aspects of cardiovascular disease (report on health and social subjects no 46). London UK: HMSO.

15. Devatkal, S., Mendiratta, S. K., Kondaiah, N., Sharma, M. C., and Anjaeyulu, A. S. R. (2004) Physicochemical, functional and microbiological quality of buffalo liver. Meat Sci. 68, 79-86.

16. Florek, M., Litwińczuk, Z., Skałecki, P., Kȩdzierska-Matysek, M., and Grodzicki, T. (2012) Chemical composition and inherent properties of offal from calves maintained under two production systems. Meat Sci. 90, 402-409.

17. Folch, J., Lees, M., and Sloane-Stanley, G. H. (1957) A simple method for the isolation and purification of total lipid from animal tissue. J. Biol. Chem. 26, 497-507.

18. Hallberg, L. and Hulthén, L. (2000) Prediction of dietary iron absorption: An algorithm for calculating absorption and bioavailability of dietary iron. Am. J. Clin. Nutr. 71, 1147-1160.

19. Hermida, M., Gonzalez, M., Miranda, M., and RodriguezOtero, J. L. (2006) Mineral analysis in rabbit meat from Galicia (NW Spain). Meat Sci. 73, 635-639.

20. Hoffman, L. C., Laubscher, L. L., and Leisegang, K. (2013) Nutritional value of cooked offal derived from free-range rams reared in South Africa. Meat Sci. 93, 696-702.

21. Honikel, K. O. (2011) Composition and Calories. In: Handbook of Analysis of Edible Animal By-Products. Nollet, L. M. L. and Toldrá, F (eds) CRC Press, Boca Raton, FL, USA, pp. 105-121.

22. Honikel, K. O. and Schwagele, F. (2007) Biochemische prozesse der fleischbildung. In Qualitat von Fleisch und Fleischwaren. Branscheid, W., Honikel, K. O., von Lengerken, G., and Troeger, K (eds) Fachverlag, Frankfurt/Main, Germany, pp.727-754.
23. Jeon, H. J., Choe, J. H., Jung, Y. K., Kruk, Z. A., Lim, D. G., and Jo, C. R. (2010) Comparison of the chemical composition, textural characteristics, and sensory properties of north and south Korean native chickens and commercial broilers. Korean J. Food Sci. Ani. Resour. 30, 171-178.

24. Jump, D. B. (2002) The biochemistry of n-3 polyunsaturated fatty acids. J. Biol. Chem. 277, 8755-8758.

25. Jung, Y. K., Jeon, H. J., Jung, S., Choe, J. H., Lee, J. H., Heo, K. N., Kang, B. S., and Jo, C. (2011) Comparison of quality traits of thigh meat from Korean native chickens and broilers. Korean J. Food Sci. Ani. Resour. 31, 684-692.

26. Kim, D. H., Cho, S. H., Kim, J. H., Seong, P. N., Lee, J. M., Jo, C., and Lim, D. G. (2009) Comparison of the quality of the chicken breasts from organically and conventionally reared chickens. Korean J. Food Sci. Ani. Resour. 29, 409-414.

27. Kim, Y. B., Jeon, K. H., Lee, N. H., and Lee, H. J. (2008) An analysis of the nutritional quality of spreadable liver product. Korean J. Food Sci. Ani. Resour. 28, 21-26.

28. Kim, Y. N. (2011) Vitamins. In: Handbook of Analysis of Edible Animal By-Products. Nollet, L. M. L. and Toldrá, F (eds) CRC Press, Boca Raton, FL, USA, pp. 161-182.

29. Kratz, M. (2005) Dietary cholesterol, atherosclerosis and coronary heart disease. Handb. Exp. Pharmacol. 170, 195-213.

30. Lebiedzinska, A. and Szefer, P. (2006) Vitamins B in grain and cereal-grain food, soy-products and seeds. Food Chem. 95, 116-122.

31. Mestre-Prates, J. A., Alfaia, C. M., Alves, S. P and BranquinhoBessa, R. J. (2011). Fatty acids. In: Handbook of Analysis of Edible Animal By-Products. Nollet, L. M. L. and Toldrá, F (eds) CRC Press, Boca Raton, FL, USA, pp. 137-160.

32. Morrison, W. R. and Smith, L. M. (1964) Preparation of fatty acid methyl esters and dimethylacetals from lipids with boron trifluoride-methanol. J. Lipid Res. 5, 600-608.

33. Nollet, L. M. L. and Toldrá, F. (2011) Introduction of Offal meat: Definitions, regions, cultures, generalities. In: Handbook of Analysis of Edible Animal By-Products. Nollet, L. M. L. and Toldrá, F (eds) CRC Press, Boca Raton, FL, USA, pp. 3-11.

34. Ockerman, H. W. and Basu, L. (2004) By-products. In: Encyclopedia of meat sciences. Jensen, W. K., Devine, C., and Dikeman, M (eds) Elsevier Academic Press, Amsterdam, London, pp. 104-112.

35. Penniston, K. L. and Tanumihardjo, S. A. (2006) The acute and chronic toxic effects of vitamin A1, 2, 3, 4. Am. J. Clin. Nutr. 83, 191-201.

36. Pereira, P. M. C. C. and Vicente, A. F. R. B. (2013) Meat nutritional composition and nutritive role in the human diet: Review. Meat Sci. 93, 586-592.

37. Ramos, A., Cabrera, M. C., and Saadoun, A. (2012) Bioaccessibility of $\mathrm{Se}, \mathrm{Cu}, \mathrm{Zn}, \mathrm{Mn}$ and $\mathrm{Fe}$, and heme iron content in un-aged and aged meat of Hereford and Braford steers fed pasture. Meat Sci. 91, 116-124.

38. SAS Institute, Inc. (2007) SAS User's Guide. Release. 9.1.3. Statistical Analysis System Institute. Cary, NC, USA.

39. Savaran, E. G. and Pavlova, V. A. (1980) Amino acid composition of soft by-product of various poultry species. Voprosy 
Pitaniya. 4, 71-74.

40. Seong, P. N., Kang, G. H., Park, K. M., Cho, S. H., Kang, S. M., Park, B. Y., Moon, S. S., and Ba, H. V. (2014b) Characterization of Hanwoo bovine by-products by means of yield, physicochemical and nutritional composition. Korean J. Food Sci. Ani. Resour. 34, 434-447.

41. Seong, P. N., Park, K. M., Cho, S. H., Kang, G. H., Kang, S. M., Park, B. Y., Moon, S. S., and Ba, H. V. (2014a) Characterization of pork by-Products by Means of Yield, Physicochemical and Nutritional Composition. Korean J. Food Sci. Ani. Resour. 34, 297-306.

42. Simpson, R. J. and Mckie, A. T. (2009) Regulation of intestinal iron absorption: The mucosa takes control? Cell Metab. 10, 84-87.

43. Spackman, D. H., Stein, W. H., and Moore, S. (1958) Automatic recording apparatus for use in chromatography of amino acids. Anal. Chem. 30, 1190-1206.
44. Tapiero, H. and Tew, K. D. (2003) Trace elements in human physiology and pathology: Zinc and metallothioneins. Biomed. Pharmacother. 57, 399-411.

45. The Poultry Site: The global poultry trends 2013. Available from: http://www.thepoultrysite.com/articles/2929/global-p oultry-trends-2013-asia-consumes-40-per-cent-of-worlds-ch ick en. Accessed Sep. 18, 2013.

46. Toldra, F., Aristoy, M. C., Mora, L., and Reig, M. (2012) Innovations in value-addition of edible meat by-products. Meat Sci. 92, 290-296.

47. Wood, J. D., Richardson, R. I., Nute, G. R., Fisher, A. V., Campo, M. M., and Kasapidou, E. (2003) Effects of fatty acids on meat quality: A review. Meat Sci. 66, 21-32.

48. Wu, G. (2010) Functional amino acids in growth, reproduction, and health. Advances in Nutrition 1, 31-37.

49. Zotte, A. D. and Szendro, Z. (2011). The role of rabbit meat as functional food. Meat Sci. 88, 319-331. 